aluminium alloys in the first instance. The facilities of the melting shop providing for work on these subjects include coko fired, gas fired and electric resistance (silit rods) crucible furnaces melting 100-120 lb. copper and a high-frequency furnace. There is also a large electric resistance annealing furnace.

The mechanical testing laboratory occupies the lowest floor of the new building. The constanttemperature room ( $480 \mathrm{sq}$. ft.) at one end is thermo. statically maintained at $20^{\circ} \mathrm{C} . \pm 0 \cdot 3^{\circ} \mathrm{C}$. by circulation of air, heated or cooled according to the outside temperature, and is equipped for creep tests. The very complete spectrographic equipment em. ployed in the Association's work on quantitative spectographic analysis of metals and alloys is housed in the large physics laboratory, the other equipment of which includes that designed by the Association's staff for the determination of thermal conductivity. and of optical reffectivity. Good provision is made, in other rooms, for the preparation, examination and photography of metallographic specimens, for pyrometry and heat treatment, and for chemical analytical work.

The top floor of the older building is deroted to corrosion research, a subject in which the Association's work tends always to increase. Condenser tubes, on which work has proceeded for so many years, have ceased to be a corrosion problem for ordinary conditions of service because of the general use of tubes made of the Association's aluminium brass or other highly resistant alloys developed by makers, but the more severe corrosive conditions sometimes encountered-bacterial action playing a part not infrequently-are the reason for work designed to produce tubes still more resistant. Other corrosion investigations are concerned with lead, copper, zine and galvanized material, and at least fivo hundred corrosion tests are in progress at the present time. The older building also contains the machine shop and galvanizing and welding laboratories, while one floor, occupied by the Development Department, includes an exhibition illustrating the practical results of the Association's researches.

The Association's annual lunch on June 29 was made the occasion for celebrating the completion of the new laboratories, and the large company assembled then proceeded to Euston Street where the building was formally opened by the President of the Board of Trade. Mr. Oliver Stanley also unveiled a memorial to the Association's chairman from 1920 to 1937 , the late Mr. Thomas Bolton, to whose leadership the success of the Association has been due in no small measure. The memorial is a cașt bronze portrait plaque, fixed on the wall of the entrance hall of the new building.

\title{
ASSOCIATION OF TECHNICAL INSTITUTIONS
}

\begin{abstract}
A $T$ the recent summer meeting of the Association $A$ of Technical Institutions, held at Harrogate, papers read included "The Present Position of Technical Education in the West Riding" (by Mr. A. L. Binns, director of education for the West Riding of Yorkshire), "Whither Technical Education?" (by Dr. T. J. Drakeley, principal of the Northern Polytechnic, London), and "'Technical and Vocational Education in the U.S.A." (by Mr. G. A. Robinson, principal of the South-East London Technical Institute).

Mr. Binns said the organization of technical edu. eation in the West Riding was on a regional basis, the machinery for which is provided by the Yorkshire Council for Further Education, which is representative of all the authorities for higher education in the area. The scheme, Mr. Binns pointed out, is a typical English solution of a problem which might elsewhere have been solved by moro autocratic methods. "It aims at combining the advantages of close local interest and initiative with those of a common policy over a wide area, and it hopes to secure these advantages by cordial co-operation among free and independent statutory bodies rather than by a policy of subordination or absorption." Elementary technical instruction is provided as close as possible to the homes of the students, while the more advanced work is concentrated progressively in centres where traffic routes converge. In connexion with the advanced work, financial arrangements have been made which leave the students free to attend the institution they prefer, whether it is within or without the boundary of a county borough. In short, the Yorkshire Council for Further Education
\end{abstract}

works to harmonize the relations between the different local authorities and the industries within the region.

Dr. Drakeley referred, during his paper, to the report on Policy in Technical Education which had been published by the associations dealing with technical education and the National Society of Art Masters. He argued for certain recommendations which he hoped would promote discussion along definite lines and secure, in the words of the above report, that the latter shall produce "not only skilled scientists, technicians and designers, but also persons adaptable to continuous industrial and economic change".

The main point put forward by Dr. Drakeley was that technical education should concern itself immediately with the training of a skilled rank and file for industry and commerce. The training provided in the schools should involve a high degree of crafts. manship, together with a good educational standard. He recommended also, however, that provision should be retained for vertical advancement by the development, where necessary, of senior day technical or trade courses from the age of 16 plus to about 19 plus, such training to lead to the more responsible posts in industry. Speaking of national defence schemes, Dr. Drakeley urged that a fraction of any expenditure on Government or industrial schemes should be set apart for the purpose of training necessary personnel. $\mathrm{He}$ also argued that in the development of all technical courses, especially those designed for the training of skilled workers, the active co-operation of employers' and employees' organizations should be obtained. 
Mr. G. A. Robinson's paper summarized the information he had obtained during two visits to the United States. His first visit was made as Page scholar, when he was able to go to certain universities with faculties of engineering and to examine their departments of industrial administration, in addition to ascertaining the progress made by summer schools (technical education) of the Oxford type. On that occasion he visited a few trade and rocational schools, but his main objectives did not lie in that field. During his second visit, in 1938, he had three objectives, namely, to attend summer schools for vocational and other teachers; to attend the Seventh
International Congress on Scientific Management, and to renew the technical contacts he had made in 1936. His paper included his comments on universities and institutes, evening instruction, vocational education, industrial economics, apprenticeship, management education and production training. In his conclusion, ho suggested that, in rocational education, Great Britain has much to learn from America, "especially under proposed changes in our secondary school system"; in technical education, horrever, ho thinks that America has equally as much to learn from Great Britain in work of the national certificate type and in high-grade craft technology.

\section{CONGRESS OF THE SOUTH-EASTERN UNION OF SCIENTIFIC SOCIETIES, I939}

\begin{abstract}
$\mathrm{T}$ HE first Congress of the South-Eastern Union of Scientific Societies held at St. Albans in 1911 showed that the effect of Queen Victoria's raising the town to the dignity of a city and appointing a bishop had not only resulted in the late Viscount Grimston restoring the Abbey of the Benedictine monastery, erected over the Saxon shrine of the first Christian martyr, to the form it took under its abbots; but also directed attention to the excavation of the sites of the three older cities of Verulamium under the superintendence of Dr. and the late Mrs. Mortimer Wheeler. The second Congress, held this year, during June 6-10, marked a second stage and showed the interest and pride which the present-day citizens, with their enlarged boundaries and modern buildings, take in their long history. The Corporation has built a fine museum specially to house the V'erulamium finds which were arranged by Mr. Philip Corder, the curator, and both he and Dr. Mortimer Wheeler were on the spot to explain and interpret the finds. A visit to the excavated amphitheatre, adapted by the Romans as a Greek theatre, is unique in Great Britain, and serves to emphasize the fact that it was the only town given the status of "Mrunicipium", thus making its inhabitants citizens of Rome and Verulamium the capital of England, with London merely its port twenty miles away.

The restoration of the Abbey for conversion into a cathedral meant the removal of the grammar school, housed in one of the aisles of its very long nave, to a site inside the old Abbey Gate, and the modern buildings with a fine school hall and lecture theatre, together with tho Abbey Institute rooms, served well for the Congress sessions and lectures. As in 1911, the old Town Hall was made available for the recep. tion of members, and here the Mayor (Councillor T. F. EIm) and local patrons welcomed the Congress and heard the presidential address given by Mr. James G. Mann, keeper of the Wallace Collection and now Master of the Armouries at the Tower of London. His subject was "The Changing Conditions in the Study of Art and Antiquity., and dealt mostly with the growth of museums during the last century, pointing out that it was almost entirely due to the enthusiasm of amateur collectors; now there is a risk in paid officials labelling and arranging their specimens and pictures for the education of students - even classes of school children unable to appreciate artistic treasures-and the true amateur is driven
\end{abstract}

to collect unwanted 'bygones' hitherto neglected by professional curators. Mr. Mann made a plea for retaining works of art in their original setting, and for dispersing to local museums representative specimens, either permanently or by rotation in loan collections, to improve provincial taste, and specializing the general museums oven in the metropolis, making some allowance for accretion.

The Archeological Section heard an address on the changing fashions in place and personal names by Mr. L. F. Salzman. The origin of many forms of place names were explained and an examination of old nominal lists, such as the poll tax required, showed that in medieval times "Mary Anne's" were rare, partly because Mary seems to have been reserved for important personages and because it was not the custom to give more than one Christian name to a girl. Although St. George has always been considered the patron saint of England, the name "George" is almost absent before the time of the Hanoverian monarch.

The address to the Botanical Section, by Mr. P. MI. Hall, was devoted to a discussion of the dozen hybrid wild orchids of Great Britain. The crosses are far more common in temperate than in tropical vegetation but it often requires microscopic examination to determine the origin of a hybrid. Dr. H. G. Thornton spoke on the investigations, undertaken at Rothamsted Experimental Station, on bacteria in the soil, which are fundamental to the science of agriculture.

Mr. D. Seth-Smith, of the Zoological Gardens, addressed the Zoological Section on "Animal Behnviour". Ho pointed out that animals brought up in captivity, though they lose the fear of man and depend upon him for food, nevertheless retain in reared generations certain wild habits; ho said that zebras are liable to panic, lions crouch on sighting a dog, deer attack familiar attendants and birds fight in nuptial display. Dr. C. B. Williams spoke of the results obtained from 800,000 insects collected in light traps of his design at Rothamsted Experimental Station in four years. The unexpected results show that the majority are Diptera and that Coleoptera rarely come to light, that at 35 feet above ground females are twice as numerous as males but not so at ground-level, that twice as many insects come to light on dark cloudy nights as in clear moonlight, and the separation of catches by hours shows the periods in which various species are active and the 